the severity of the clinical symptoms could not be adequately explained by valvular regurgitation, of which there was little evidence on examination of the heart. Blood cultures usually remained sterile, presumably because of inappropriate antibiotic treatment or the limited infectiveness of the organisms present, or both.

A striking feature in three patients (cases 1, 2, and 4) was the acute, severe, and rapidly resolving but recurrent episodes of pulmonary oedema. Possibly these were caused by sudden blocking of the orifice by vegetation-this was indeed shown echocardiographically in one patient (case 4). Other patients (cases 3 and 5 and those reported by Reeve et $a^{1}$ and Matula et $a l^{2}$ ) had more progressive pulmonary oedema, suggesting increasing mitral stenosis. In our experience both types of pulmonary oedema are uncommon in patients with isolated mitral valve regurgitation during bacterial endocarditis.

Those of our patients who did not have mitral valve replacement (cases 2, 4, and 5) and the patient of Reeve and his colleagues $^{1}$ had a sudden cardiac arrest. Mitral valve vegetations cause obstruction just as catastrophic as an atrial tumour or a ball thrombus, and hence once the doctor suspects mitral valve obstruction he should confirm the diagnosis promptly and ensure that the patient is rapidly operated on.

Accurate diagnosis is vital. Right heart catheterisation showed a raised pulmonary wedge pressure without a striking $\mathrm{V}$ wave, but was nevertheless of little value in assessing the severity of the haemodynamic disturbance: pressures may be very high because of rheumatic valve disease (case 4) or only moderately increased because the obstruction is intermittent. Echocardiography is the only method of detecting valvular vegetations directly: bulky vegetations such as occurred in these patients are unlikely to be missed. The technique has only a limited sensitivity, however, in mitral valve endocarditis. ${ }^{45}$ Linear echoes behind the mitral valve should not be confused with atrial myxoma $^{6}$; fungal, ${ }^{7}$ marantic, ${ }^{8}$ or granulomatous ${ }^{9}$ obstruction; or thrombus.

Hence whenever pulmonary oedema occurs in a patient with fever, haemodynamic oedema resulting from bacterial endocarditis should be suspected routinely even if the findings on cardiac auscultation are normal. A viral origin is unlikely if fever continues for more than a week. Cardiac catheterisation may not confirm the diagnosis and echocardiography should be used. When this gives abnormal echoes behind the mitral valve in a patient with the typical history and other features, emergency surgery should be carried out because of the risk of sudden death.

We thank Professor P Soyer, Professor E Hazan, Dr J P Bex, and Dr Y Leconte, who operated on our patients, and Dr C Bouton who performed the necropsies.

\section{References}

${ }^{1}$ Reeve, R, et al, fournal of the American Medical Association, 1974, 228, 75 2 Matula, G, et al, fournal of the American Medical Association, 1975, 233, 58.

${ }^{3}$ Roberts, W C, et al, Circulation, 1967, 36, 449.

4 Roy, P, et al, Circulation, 1976, 53, 474.

5 Wann, P, et al, New England fournal of Medicine, 1976, 295, 135.

- Hirschfeld, D S, and Emilson, B B, Western fournal of Medicine, 1976, 124, 419.

7 Pasternak, R C, et al, British Heart fournal, 1976, 38, 1209.

${ }^{8}$ Estevez, C M, and Corya, B C, Chest, 1976, 69, 801.

${ }^{9}$ Fitchett, D H, and Oakley, C M, British Heart fournal, 1976, 38, 316.

\title{
Study of 8-year-old children with a history of respiratory syncytial virus bronchiolitis in infancy
}

\author{
D G SIMS, M A P S DOWNHAM, P S GARDNER, J K G WEBB, D WEIGHTMAN
}

British Medical fournal, 1978, 1, 11-14

\section{Summary and conclusions}

Thirty-five children known to have had respiratory syncytial virus bronchiolitis in infancy were examined at the age of 8 and their respiratory function tested. The results were compared with those in 35 controls matched for age, sex, and social class.

Although 18 of the children who had had bronchiolitis in infancy had experienced subsequent episodes of wheezing, these were neither severe nor frequent in most cases and had apparently ceased by the age of 8 . Nevertheless, the mean exercise bronchial lability of the children who had had bronchiolitis was significantly higher than that of the control children and the mean peak expiratory flow rate at rest significantly lower.

University of Newcastle upon Tyne, Newcastle upon Tyne D G SIMS, MB, MRCP, senior research associate in child health and virology $M$ A P S DOWNHAM, MRCP, DCH, senior lecturer in child health $P$ S GARDNER, MD, DIPBACT, professor of clinical virology J K G WEBB, MA, FRCP, professor of child health

D WEIGHTMAN, assistant in medical statistics
Atopy, assessed by family and personal history alone, did not seem to be related to either bronchiolitis or wheezing episodes after bronchiolitis. The parents of the children who had had bronchiolitis smoked significantly more cigarettes during the infant's first year of life than those of the control children.

The results suggest that bronchiolitis and childhood asthma are not closely related. Bronchial hyperreactivity might be inherited independently of atopy, but environmental factors seem the most likely link between severe respiratory infection in infancy and chronic or recurrent respiratory illness in adult life.

\section{Introduction}

Does lower respiratory tract infection in infancy increase the risk of recurrent or chronic respiratory disease in later life? Difficult though this question is the answer may provide important new incentives for preventing and managing severe respiratory illness at all ages, and in recent years relevant evidence has been accumulating. A history of lower respiratory tract illness in early childhood has been shown to be associated with an increased incidence of respiratory symptoms and impaired ventilatory function in later childhood and early adult life. ${ }^{1-5}$ Many children with a history of recurrent wheezing become symptom free but respond abnormally to exercise 
tests. ${ }^{6}$ In all these studies, however, the definition of the early illness has been uncertain, depending largely on parental diagnosis or on retrospective clinical judgment.

Respiratory syncytial (RS) virus bronchiolitis is the commonest severe lower respiratory tract infection in infancy. Its characteristic clinical picture and viral cause provide an opportunity to define a more homogeneous group of children for follow-up studies. Rooney and Williams ${ }^{7}$ followed such a group, and their finding that 35 out of 62 children known to have had $R S$ virus bronchiolitis in infancy developed subsequent wheezing episodes has often been quoted. Their study was not controlled, however, and at follow-up the children's ages ranged from 2 to 7 years.

We therefore identified a group of children who had had RS virus bronchiolitis in infancy and studied them eight years later. The assessment included tests of respiratory function as well as history and examination. Information was gathered about manifestations of atopy and smoking habits in the child's family, as both may be relevant to the development of recurrent or chronic respiratory illness. All the results were compared with those from a control group of children matched by age, sex, and social class and known not to have been admitted with bronchiolitis in infancy. The Newcastle Area Health Authority Ethical Committee agreed to the study.

\section{Method}

The records of all infants from whom RS virus was isolated in the winter epidemic of 1967-8 were examined. Fifty-six infants (29 girls and 27 boys) had one or more signs of bronchiolitis recorded and were selected. One of the 56 children had since died of aspiration pneumonia after ingesting polystyrene fragments, and two had emigrated. No attempt was made to contact a child with multiple congenital abnormalities and another with severe mental retardation. Of the remainder, four lived 100 miles or more away, two could not be traced, and five refused to attend for follow-up.

We were able to match 35 children closely with 35 controls and these were included in the study. At the time of their admission in infancy with RS virus bronchiolitis wheezing had been recorded in 33 , chest recession in 30 , crepitations in 29 , and clinically detectable overinflation in nine. Radiological appearances of the chest had been reported as being normal in 11 and showing overinflation in 15, subsegmental collapse or consolidation in 11, peribronchial thickening in six, and segmental consolidation in one. Clinically this child with segmental consolidation had had recession, wheezing, and bilateral crepitations.

The 35 children were reviewed with one or both parents and details of subsequent respiratory illnesses were obtained. Parents were asked whether the child or any first-degree relatives had a history of wheezing (they were asked: "Has a whistling sound ever come from the chest ?" and the sound was demonstrated by a forced expiration); eczema (a red, flaking, itchy rash); allergic rhinitis (nasal discharge, sneezing, or irritation of the eyes at certain times of the year or with specific allergens); urticaria (pale, itchy, raised bumps on the skin); or rashes in response to food or drugs. Family smoking habits during the child's first year of life and currently were recorded. The weight and height of each child was noted and the upper and lower respiratory tract examined clinically. Resting values of forced expiratory volume in 0.75 second $\left(\mathrm{FEV}_{0 \cdot 75}\right)$ and vital capacity (VC) were measured using a Vitalograph spirometer. The peak expiratory flow rate (PEFR) was measured with a Wright's peak flow meter, and the value was taken as the best of three readings after the child had become accustomed to the procedure and was giving consistent values. The child then ran for six minutes round a quadrangle or up and down a corridor and the pulse was counted. PEFR readings were obtained during a pause for a few seconds three minutes after starting to run, and at one, three, five, 10 , and 15 minutes after completing the run. From these readings the maximum percentage rise and fall of PEFR were determined. Exercise-induced bronchial lability was expressed as the sum of the percentage maximum rise and fall of PEFR. ${ }^{6}$ One child had a PEFR at rest of less than $50 \%$ of the expected mean normal and was therefore not exercised.

Control children were identified by giving lists containing the sex, age, and social class of the index children to the headteachers of four Tyneside schools. The headteachers were asked to select children of the same sex and age to within two months and to attempt to match the social class using father's occupation as a guide. The parents then were approached by letter. Thirty-five children were investigated by the same methods as the index children. None of the control children had been admitted to hospital during the first year of life with respiratory illness. All the interviews and tests were carried out by the same person.

Results were compared using Student's $t$ test for matched pairs, $\chi^{2}$ tests, and exact probability tests for qualitative data.

\section{Results}

\section{COMPARABILITY OF THE TWO GROUPS}

The only significant difference between the groups was in the mean number and age of siblings, both of which were greater in the bronchiolitis group (table I).

\section{CLINICAL HISTORY AND EXAMINATION}

Eighteen of the children who had had bronchiolitis gave a history of wheezing on one or more occasions since their bronchiolitis compared with only one of the control group $(P<0.0005)$. The wheezing episodes experienced subsequently by the children who had had bronchiolitis were, however, neither severe nor frequent enough to have resulted in hospital outpatient or inpatient referral. The episodes were often absent for long periods, and 10 of the 18 children had experienced no wheezing at all in the two years before interview.

There was a slightly higher incidence of a history of upper respiratory tract infections and croup among the children who had had bronchiolitis, but this difference did not reach statistical significance.

Routine physical examination of the upper and lower respiratory tract showed no significant differences between the two groups.

\section{TESTS OF RESPIRATORY FUNCTION}

Table II shows the mean values for $\mathrm{FEV}_{0 \cdot 75}$, VC, PEFR at rest, and $\mathrm{FEV}_{0.75}$ as a percentage of VC. The PEFR values were significantly lower in the children with a history of bronchiolitis $(P<0.02)$ No significant difference was demonstrable between the groups for $\mathrm{FEV}_{0.75}$ or VC values, but for the $\mathrm{FEV}_{0 \cdot 75}$ expressed as a percentage of the VC the mean value in the bronchiolitis group was lower by $4 \cdot 1 \%$, which was statistically significant $(P<0 \cdot 05)$.

Immediately after exercise the mean pulse rate was $182+12 \cdot 1$ beats $/ \mathrm{min}$ in the bronchiolitis group and $184 \pm 19.5$ beats $/ \mathrm{min}$ in the controls, suggesting that exertion was comparable in the two groups

TABLE I-Comparability of the two groups of children studied. Results are means $\pm S D$

\begin{tabular}{|c|c|c|c|c|c|c|c|c|c|c|c|}
\hline \multirow{2}{*}{ Group } & \multirow{2}{*}{$\begin{array}{l}\text { No of } \\
\text { children }\end{array}$} & \multirow{2}{*}{$\underset{(\mathrm{F} / \mathrm{M})}{\operatorname{Sex}}$} & \multirow{2}{*}{$\begin{array}{c}\text { Mean } \\
\text { birth } \\
\text { weight } \\
\text { (kg) }\end{array}$} & \multirow{2}{*}{$\begin{array}{c}\text { Mean } \\
\text { age at } \\
\text { interview } \\
\text { (years) }\end{array}$} & \multirow{2}{*}{$\begin{array}{c}\text { Mean } \\
\text { current } \\
\text { weight } \\
(\mathrm{kg})\end{array}$} & \multirow{2}{*}{$\begin{array}{l}\text { Mean } \\
\text { current } \\
\text { height } \\
(\mathrm{cm})\end{array}$} & \multirow{2}{*}{$\begin{array}{l}\text { Mean } \\
\text { No of } \\
\text { siblings }\end{array}$} & \multirow{2}{*}{$\begin{array}{l}\text { Mean } \\
\text { age of } \\
\text { siblings } \\
\text { (years) }\end{array}$} & \multicolumn{3}{|c|}{ Social class distribution } \\
\hline & & & & & & & & & I and II & III & $\begin{array}{c}\mathrm{IV}, \mathrm{V}, \text { and } \\
\text { ether* }\end{array}$ \\
\hline $\begin{array}{l}\text { Bronchiolitis } \\
\text { Control }\end{array}$ & $\begin{array}{l}35 \\
35\end{array}$ & $\begin{array}{l}18 / 17 \\
18 / 17\end{array}$ & $\begin{array}{l}3.22 \pm 0.49 \\
3.32 \pm 0.46\end{array}$ & $\begin{array}{l}8.32 \pm 0.28 \\
8.40 \pm 0.33\end{array}$ & $\begin{array}{l}26 \cdot 58 \pm 4 \cdot 00 \\
26 \cdot 20 \pm 3 \cdot 95\end{array}$ & $\begin{array}{l}127 \cdot 9 \pm 6.39 \\
126 \cdot 4 \div 5 \cdot 25 \\
\end{array}$ & $\begin{array}{l}2.1 \pm 1.45 \\
1.3 \pm 0.86\end{array}$ & $\begin{array}{r}10 \cdot 9 \pm 5 \cdot 13 \\
8 \cdot 5 \pm 4 \cdot 17\end{array}$ & $\begin{array}{l}2 \\
3\end{array}$ & $\begin{array}{l}19 \\
23\end{array}$ & $\begin{array}{r}14 \\
9\end{array}$ \\
\hline \multicolumn{3}{|c|}{$\begin{array}{l}\text { Mean difference } \\
\text { Standard error of difference within pairs } \\
\mathbf{P} \text { value } \neq\end{array}$} & $\begin{array}{l}-0 \cdot 10 \\
0 \cdot 122 \\
>0 \cdot 4\end{array}$ & $\begin{array}{l}-0.08 \\
0.042 \\
>0.05\end{array}$ & $\begin{array}{l}+0.38 \\
1.013 \\
>0.7\end{array}$ & $\begin{array}{l}+1.5 \\
>0.490\end{array}$ & $\begin{array}{l}+0.8 \\
0.315 \\
<0.02\end{array}$ & $\begin{array}{l}+2.4 \dagger \\
0.943 \\
<0.02\end{array}$ & \multicolumn{3}{|c|}{$\chi^{2}(\mathrm{DF}=1)=1.619 ; \mathrm{P}>0.2$} \\
\hline
\end{tabular}


TABLE II-Results of tests of respiratory function made at rest

\begin{tabular}{|c|c|c|c|c|c|}
\hline Group & $\begin{array}{c}\text { No of } \\
\text { matched } \\
\text { pairs }\end{array}$ & $\begin{array}{l}\text { Mean } \\
\text { value }\end{array}$ & $\begin{array}{c}\text { Mean } \\
\text { difference }\end{array}$ & $\begin{array}{l}\text { Standard } \\
\text { error of } \\
\text { difference }\end{array}$ & $\mathbf{P}$ \\
\hline \multicolumn{6}{|c|}{$F E V_{0.75}(l)$} \\
\hline $\begin{array}{l}\text { Bronchiolitis } \\
\text { Control }\end{array}$ & 35 & $\begin{array}{l}1.59 \\
1.64\end{array}$ & -0.05 & 0.067 & $>0.4$ \\
\hline \multicolumn{6}{|c|}{$V C(l)$} \\
\hline $\begin{array}{l}\text { Bronchiolitis } \\
\text { Control }\end{array}$ & 34 & $\begin{array}{l}1.95 \\
1.89\end{array}$ & +0.06 & 0.084 & $>0.4$ \\
\hline \multicolumn{6}{|c|}{ PEFR $(l / \min )$} \\
\hline $\begin{array}{l}\text { Bronchiolitis } \\
\text { Control }\end{array}$ & 35 & $\begin{array}{l}237 \cdot 3 \\
265 \cdot 1\end{array}$ & $-27 \cdot 8$ & $11 \cdot 358$ & $<0.02$ \\
\hline \multicolumn{6}{|c|}{$F E V_{0 \cdot 78} / V C \times 100$} \\
\hline $\begin{array}{l}\text { Bronchiolitis } \\
\text { Control }\end{array}$ & 34 & $\begin{array}{l}83.2 \\
87.3\end{array}$ & $|-4 \cdot 1|$ & 1.827 & $<0.05$ \\
\hline
\end{tabular}

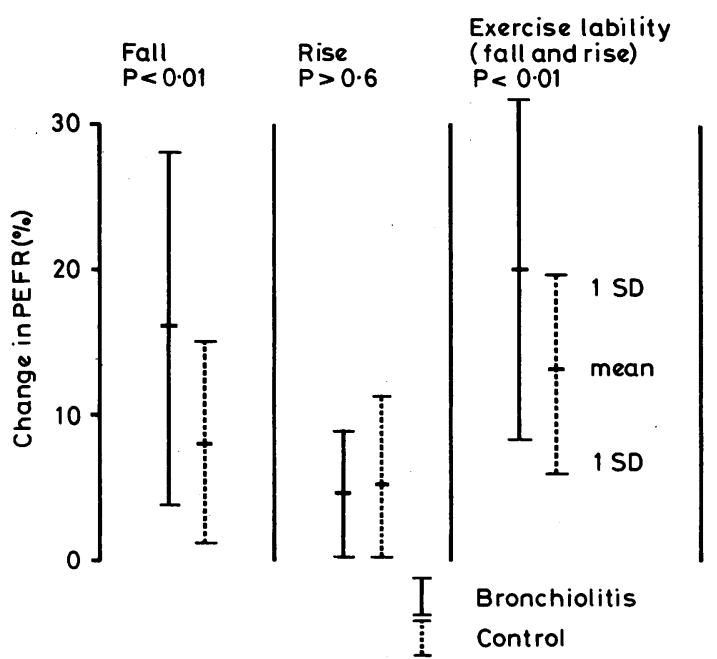

Mean $( \pm \mathrm{SD})$ PEFR change in response to exercise for bronchiolitis and control groups. Comparisons were made in matched subjects.

$(\mathbf{P}>0.5)$. The figure shows the mean indices of bronchial lability. The mean differences in values for percentage fall and for exercise lability were significant $(P<0.01)$. Exercise testing precipitated symptoms in two children: one child in the bronchiolitis group with an exercise lability of $70 \%$ developed severe wheezing, and one control child with an exercise lability of $35 \%$, whose parents had never noticed wheezing previously, had a transient episode of coughing and wheezing after the test.

\section{ATOPY}

The prevalence of clinical features of atopy in the children and their first-degree relatives was similar in the two groups.

\section{PARENTAL SMOKING HABITS}

During the infant's first year of life $71 \%$ of the mothers of children who had had bronchiolitis had smoked compared with $49 \%$ of control mothers, a difference that just failed to reach statistical significance ( $\chi^{2}$ with $\left.1 \mathrm{DF}=3.81 ; \mathrm{P}>0.05\right)$. More fathers of children in the bronchiolitis group had smoked $(77 \%)$ than control fathers $(60 \%)$ but this difference was not significant $(\mathbf{P}>0 \cdot 1)$.

Together the parents of children who had had bronchiolitis had smoked on average 29.1 cigarettes/day during the first year of the infant's life, compared with 19.6 smoked by the control parents. This gave a mean difference of 9.5 cigarettes/day with a standard error of $4 \cdot 125$, which was significant $(P<0.05)$.

At the time of the study the parents whose children had had bronchiolitis smoked on average 29.2 cigarettes/day and the control parents $21 \cdot 1$, a mean difference of $8: 1$ with a standard error of 4.947. This was not statistically significant $(P>0 \cdot 1)$.

\section{COMPARISONS WITHIN BRONCHIOLITIS GROUP}

Further analyses were made after dividing the bronchiolitis group into those with a subsequent history of wheezing (18 children), and those without (17 children). No significant differences in sex distribution, social class, age at interview, birth weight, or current weight and height emerged when these subgroups were compared. Retrospective analysis of details of the original admission for bronchiolitis with respect to age, weight, use of antibiotics, length of hospital stay, physical signs, and radiological findings, showed no differences. There were also no differences in the prevalence of atopy or in parental smoking habits.

Table III gives results of lung function tests at rest and during exercise for the wheezing group, the non-wheezing group, and the controls. The PEFR values at rest, the fall in PEFR during exercise, and overall exercise lability showed a consistent trend, the wheezing children performing worse than the non-wheezing children, who in turn performed worse than the controls. There was no such trend for the rise in PEFR during exercise.

\section{Discussion}

Eighteen of the children with a history of RS virus bronchiolitis suffered subsequent wheezing, but it was rarely severe, was often absent for long periods, and in most cases had apparently ceased by the age of 8 . We therefore suggest that the clinical prognosis for a baby with RS virus bronchiolitis is good, at least at the age of 8 , and disagree with Rooney and Williams's conclusion that there may be a strong association between bronchiolitis and unequivocal asthma. ${ }^{7}$ There does, however, seem to be an association with the syndrome described by Williams and $\mathrm{McNicol}^{8}$ of mild infrequent wheezing episodes that resolve by the age of 8 . Leeder et $a l^{9}$ have recently shown that there is a relation between a history of pneumonia or bronchitis in infancy and subsequent wheezing and that this relation is stronger for wheezing not regarded by parents as "asthmatic."

Exercise lability studies at this age have not been reported in a group of this size. The test was performed with ease on most of the children, but a few needed extra encouragement and a

TABLE III-Results of lung function tests in bronchiolitis group subdivided into those with and those without a history of subsequent wheeze and compared with their matched controls

\begin{tabular}{|c|c|c|c|c|c|c|c|c|}
\hline & \multicolumn{2}{|c|}{$\underset{(1 / \mathrm{min})}{\text { PEFR at rest }}$} & \multicolumn{2}{|c|}{$\underset{(\%)}{\operatorname{Maximum} \text { rise in PEFR }}$} & \multicolumn{2}{|c|}{$\underset{(\%)}{\text { Maximum fall in PEFR }}$} & \multicolumn{2}{|c|}{$\begin{array}{c}\text { Exercise lability } \\
(\%)\end{array}$} \\
\hline & No & Mean \pm SD & No & Mean \pm SD & No & Mean \pm SD & No & Mean \pm SD \\
\hline $\begin{array}{l}\text { Bronchiolitis-further wheezing (A) } \\
\text { Controls (CA) } \\
\text { Bronchiolitis-no further wheezing (B) } \\
\text { Controls (CB) }\end{array}$ & $\begin{array}{l}18 \\
18 \\
17 \\
17\end{array}$ & $\begin{array}{l}226 \cdot 4 \pm 49 \cdot 5 \\
269 \cdot 4 \pm 49 \cdot 6 \\
248 \cdot 8 \pm 35 \cdot 4 \\
260 \cdot 6 \pm 37 \cdot 4\end{array}$ & $\begin{array}{l}17^{*} \\
17 \\
17 \\
17\end{array}$ & $\begin{array}{l}5 \cdot 6 \pm 4 \cdot 9 \\
3 \cdot 9 \pm 4 \cdot 4 \\
2 \cdot 8 \pm 3 \cdot 5 \\
5 \cdot 6 \pm 7 \cdot 4 \\
\end{array}$ & $\begin{array}{l}17^{*} \\
17 \\
17 \\
17\end{array}$ & $\begin{array}{c}17 \cdot 1 \pm 15 \cdot 9 \\
7 \cdot 4 \pm 5 \cdot 7 \\
14 \cdot 3 \pm 6 \cdot 9 \\
8 \cdot 4 \pm 8 \cdot 1 \\
\end{array}$ & $\begin{array}{l}17^{*} \\
17 \\
17 \\
17\end{array}$ & $\begin{array}{l}22 \cdot 7 \pm 15 \cdot 0 \\
11 \cdot 3 \pm 4 \cdot 7 \\
17 \cdot 1 \pm 6 \cdot 0 \\
14 \cdot 0 \pm 8 \cdot 3\end{array}$ \\
\hline $\begin{array}{l}\text { Significance: } \\
\mathbf{A} v \mathbf{B} \\
\mathbf{A} v \mathbf{C A} \\
\mathbf{B} v \mathbf{C B}\end{array}$ & \multicolumn{2}{|c|}{$\begin{array}{c}>0.1 \\
0.02 \\
>0.4\end{array}$} & \multicolumn{2}{|c|}{$\begin{array}{l}>0.05 \\
>0.3 \\
>0.2\end{array}$} & \multicolumn{2}{|c|}{$\begin{array}{l}\geq 0.5 \\
<0.05 \\
<0.05\end{array}$} & \multicolumn{2}{|c|}{$\begin{array}{l}>0.1 \\
<0.02 \\
>0.2\end{array}$} \\
\hline
\end{tabular}

*Values in one subject were not measured. 
few were so eager to oblige that they were inclined to blow hurriedly into the peak flow meter without inhaling fully unless closely watched. The mean exercise lability of the children who had had bronchiolitis in infancy was significantly higher than that of the control children and the mean PEFR at rest significantly lower. Whether these findings have implications for the development of chronic respiratory illness in adult life will be known only after many years of further observation.

Rooney and Williams ${ }^{\text {? }}$ thought that they had shown an association between family atopy and the development of wheezing episodes after bronchiolitis, but their data were incomplete, and some of their younger children may have developed wheezing later in childhood after a latent period. In our study there was no apparent link between atopy and either bronchiolitis or subsequent wheezing. Clinical questioning, however, is an unreliable measure of atopy and we plan to investigate the two groups of children further by skin tests and IgE estimations.

Our results suggest that cigarette smoking by the parents during the infant's first year of life may be associated with an increased risk of RS virus bronchiolitis for their baby. To establish this a study of smoking and non-smoking parents would be necessary. Similar associations between parental smoking and lower respiratory tract infection in infancy have been found by other investigators. ${ }^{10-12}$

There are three possible ways in which respiratory disease in infancy may be linked with that in later life: there may be a causal link between the two, a genetic predisposition to both, or common environmental factors. Of the three, a causal link, although it cannot be excluded, is perhaps unlikely in view of the small degree of respiratory disability we found in the 8-year-old children who had had bronchiolitis in infancy and the long symptom-free period that many of them had experienced. We have so far been unable to show that atopy constitutes a genetic link. McNicol and Williams have already speculated that bronchial hyperreactivity may be inherited independently of atopy, ${ }^{13}$ and the results of our exercise tests are not inconsistent with this suggestion.

Environmental factors such as overcrowded housing, family size, air pollution, and cigarette smoking are increasingly recognised as influencing the prevalence of respiratory illness in children as well as adults. ${ }^{131415}$ Parental smoking was more common and family size larger in our bronchiolitis group, and the persistence of these factors may explain, at least in part, why many children went on to have further episodes of wheezing with impaired ventilatory function. Matching groups of children by father's occupation conceals wide variations in the way children are cared for, ${ }^{16}$ and a search for more subtle differences in the home environment between children with and without respiratory disease may disclose new opportunities for prevention.

We are grateful to the four headmasters for their help in identifying the control children and providing facilities for testing them and to the Medical Research Council for their support.

\section{References}

${ }^{1}$ Colley, J R T, and Reid, D D, British Medical fournal, 1970, 2, 213.

2 Colley, J R T, Douglas, J W B, and Reid, D D, British Medical fournal, $1973,3,195$.

${ }^{3}$ Lunn, J E, Knowelden, J, and Handyside, A J, British fournal of Preventive and Social Medicine, 1967, 21, 7.

4 Holland, W W, et al, British Medical fournal, 1969, 2, 205.

${ }^{5}$ Leeder, S R, et al, British fournal of Preventive and Social Medicine, 1976, 30, 219.

${ }^{6}$ Konig, P, Godfrey, S, and Abrahamov, A, Archives of Disease in Childhood, $1972,47,578$.

${ }^{7}$ Rooney, J C, and Williams, H E, Fournal of Pediatrics, 1971, 79, 744.

8 Williams, H, and McNicol, K N, British Medical fournal, 1969, 4, 321.

Leeder, S R, et al, British fournal of Preventive and Social Medicine, 1976, 30, 213.

${ }^{10}$ Leeder, S R, et al, British fournal of Preventive and Social Medicine, 1976, 30, 203.

${ }_{11}$ Colley, J R T, Holland, W W, and Corkhill, R T, Lancet, 1974, 2, 1031.

12 Harlap, S, and Michael Davies, A, Lancet, 1974, 1, 529.

${ }_{13}$ McNicol, K N, and Williams, H E, British Medical fournal, 1973, 4, 12.

${ }^{14}$ Colley, J R T, British Medical Bulletin, 1971, 27, 9.

15 Sims, D G, et al, British Medical fournal, 1976, 2, 1095.

${ }^{16}$ Neligan, G A, and Prudham, D, Archives of Disease in Childhood, 1976, $51,853$.

(Accepted 12 October 1977)

\title{
Antinuclear antibodies in patients receiving non-practolol beta-blockers
}

\author{
J D WILSON, JOCELYN Y BULLOCK, D C SUTHERLAND, C MAIN, K P O'BRIEN
}

British Medical fournal, 1978, 1, 14-16

\section{Summary and conclusions}

Antinuclear antibodies (ANA) were found in 54 (7.0\%) out of 767 treated hypertensive patients compared with $59(2 \cdot 4 \%)$ out of 2470 healthy controls. Inclusion of a non-practolol beta-blocker in the treatment regimen

\footnotetext{
Department of Medicine, University of Auckland School of Medicine, Auckland, New Zealand

J D WILSON, FRCP, FRCPA, associate professor in immunology

JOCELYN Y.BULLOCK, technologist

D C SUTHERLAND, MRACP, MRC research training fellow

C MAIN, MSC, postgraduate student
}

Hypertension Clinic, Auckland Hospital, Auckland, New Zealand K P O'BRIEN, MRCP, FRACP, senior physician in cardiology did not significantly affect the incidence of ANA. ANA was found in significantly more patients being treated with methyldopa (13.0\%) than patients receiving other hypotensive agents (3.8\%). Non-practolol beta-blockers in combination with methyldopa did not increase the incidence of ANA further.

\section{Introduction}

Recognition that patients taking the beta-adrenoceptorblocking drug practolol may develop serious oculomucocutaneous reactions ${ }^{1}$ has raised concern about the toxicity of related drugs. There is little evidence that non-practolol beta-blockers induce similar reactions, despite the awareness of practitioners and government agencies of side effects. Practolol toxicity was not recognised until cumulative experience with the drug totalled one million patient-years, ${ }^{2}$ and some patients developed symptoms only after many months of treatment or even after the 